\title{
BELENGGU PRODUK MODERNISASI TERHADAP DISPARITAS SISWA (STUDI KASUS PENGGUNAAN HANDPHONE DI SMA MUHAMMADIYAH SUNGGUMINASA)
}

\author{
Rinaldi ${ }^{1}$ Nurdin $^{2}$ Kaharuddin ${ }^{3}$ \\ ${ }^{1}$ Pendidikan Sosiologi, Universitas Muhammadiyah Makassar \\ Email: rinaldiinal97@gmail.com \\ ${ }^{2}$ Pendidikan Sosiologi, Universitas Muhammadiyah Makassar \\ Email: nurdin@unismuh.ac.id \\ ${ }^{3}$ Pendidikan Sosiologi, Universitas Muhammadiyah Makassar \\ Email: kaharuddin@unismuh.ac.id
}

\begin{abstract}
Result of research of usage of handphone environment of Muhammadiyah Sungguminasa Hing School cause impact of posistif impact and of negative but most impact of negative which ditimbukan like, existence of distance between student in the case of communications where nearby student but seldom happened interaction because of each business with its handphone, student play handphone at the of study take place, downhill of it motivation learn student so that influence achievement learn him.

Problem of usage of handphone environment of Muhammadiyah Sungguminasa Hing School can overcome by taking positive side him by exploiting handphone toward which posistif like, searching lesson items which no in schoolbook. Usage of handphone in school environment may not let it go hang and that hard also to be avoided because is true now modernization epoch which where ketiuka unable to use existing technology hence will cause left behind, com into question usage of handphone have to face by exploiting him as source of study because coverage of that internet very wide which we can access as according to items to study.
\end{abstract}

Keyword: Shackles, Modernization, Diparity, Handphone and Lerning achievements.

Abstrak. Hasil penelitian dari penggunaan handphone di lingkungan SMA Muhammadiyah Sungguminasa menyebabkan dampak posistif dan dampak negative tapi kebanyakan dampak negative yang ditimbukan seperti, adanya jarak antar siswa dalam hal komunikasi dimana siswa berdekatan tapi jarang terjadi interaksi dikarenakan masing-masing sibuk dengan handphone nya, siswa main handphone pada saat pembelajaran berlangsung, menurunnya motivasi belajar siswa sehingga mempengaruhi prestasi belajarnya.

Masalah penggunaan handphone di lingkungan SMA Muhammadiyah Sungguminasa bisa diatasi dengan mengambil sisi positifnya dengan memanfaatkan handphone kearah yang posistif seperti, mencari materi pelajaran yang tidak ada dalam buku pelajaran. Penggunaan handphone di lingkungan sekolah tidak boleh dibiarkan begitu saja dan itu juga susah untuk dihindari karena memang sekarang zaman modernisasi yang dimana ketika tidak mampu menggunakan teknologi yang ada maka akan menyebabkan ketertinggalan, jadi masalah penggunaan handphone harus dihadapi dengan memanfaatkannya sebagai sumber pembelajaran karena cakupan dari internet itu sangat luas yang bisa kita akses sesuai dengan materi yang akan dipelajari.

Kata kunci: Belenggu, Modernisasi, Disparitas, Handphone, Prestasi Belajar. 


\section{PENDAHULUAN}

Indonesia merupakan negara berkembang masih jauh rasanya untuk menjadi negara yang memiliki masyarakat modern. Walaupun di wilayah ibu-ibu kota di Indonesia sudah banyak hal-hal yang bersifat modern yang sudah bisa dirasakan oleh masyarakat yang ada namun sayangnya hal-hal tersebut belum bisa dirasakan sepenuhnya oleh masyarakat yang ada di Indonesia, wilayah-wilayah terpencil masih sulit rasanya untuk dapat merasakan modernisasi yang sudah terjadi di Indonesia karena mungkin salah satu faktor yang menghalangi hal itu adalah sulitnya transportasi untuk dapat sampai di wilayah tujuan.

Tujuan adanya modernisasi adalah agar menciptakan perubahan ke arah yang lebih baik, contohnya dalam bidang komunikasi. Bidang komunikasi di era modernisasi ini rasanya sangat cepat berkembang, semua hal dapat dilakukan dalam genggaman tangan dan ketukan jari. Bila Indonesia tidak bisa mengikuti perkembangan dalam bidang komunikasi tentunya akan menciptakan kesenjangan sosial dengan negara-negara tetangga. Untuk itu kita sebagai masyarakat harus dapat dengan sigap menanggapi hal-hal seperti itu.

Modernisasi merupakan proses pergeseran sikap dan mentalitas sebagai warga masyarakat untuk dapat hidup sesuai dengan tuntutan masa kini. Modernisme adalah sebuah proses yang terus berlangsung dari masa ke masa dan menghasilkan berbagai produk berupa pola hidup, kebudayaan dan banyak aspek lainnya. Fenomena modernisme, yang diyakini sebagai pilihan tepat membebaskan manusia dari situasi ketertinggalan, keterbelakangan, kemiskinan, kebodohan, meski dalam arti terbatas menunjukkan kemajuan yang cukup spektakuler, tetapi juga menyisakan persoalan-persoalan yang cukup rumit dan kompleks. Modernisme, dengan demikian, disamping menawarkan kemudahan-kemudahan bagi manusia, juga memproduksi model-model belenggu baru yang jauh lebih dahsyat.

Suatu titik terang yang bermula pada suatu kesederhanaan pada kehidupan manusia, telah menjadi sesuatu yang bermanfaat untuk mempermudah semua aspek kehidupan yang bernama teknologi. Dunia informasi saat ini seakan tidak bisa terlepas dari teknologi. Konsumsi masyarakat akan teknologi menjadikan dunia teknologi semakin lama semakin canggih komunikasi yang dulunya memerlukan waktu yang lama dalam penyampaiannya kini dengan teknologi segalanya menjadi sangat dekat dan tanpa jarak.

Awalnya, teknologi diciptakan untuk mempermudah setiap kegiatan manusia. Lahir dari pemikiran manusia yang berusaha untuk mempermudah kegiatan-kegiatannya yang kemudian diterapkan dalam kehidupan. Kini teknologi telah berkembang pesat dan semakin maju seiring dengan perkembangan zaman sehingga terjadi pengalihan fungsi teknologi. Contohnya pada salah satu fasilitas canggih pada masa ini yang akan dibahas yaitu mengenai telepon genggam yang lebih dikenal dengan sebutan handphone.

Beberapa tahun yang lalu handphone hanya dimiliki oleh kalangan pembisnis yang memang benar-benar membutuhkan itu untuk kelancaran pekerjaannya. Seiring berjalannya waktu handphone bisa dimiliki oleh semua kalangan. Baik yang sangat membutuhkan maupun yang kurang membutuhkan. Termasuk pelajar perkembangan teknologi semakin memasyarakat dikalangan pelajar. Kini handphone adalah sakunya seorang pelajar,hampir semua anak didik mengantongi handphone. Hal ini merupakan kebanggan bagi Orang tua, karena mempunyai anak yang tidak ketinggalan zaman. Orang tua menyadari akan pentingnya handphone bagi anaknya dengan berbagai alasan, namun Orang tua tidak menyadari bahwa disamping itu handphone juga mempunyai dampak negatif.

Menurut App Annie, warga Indonesia menjadi negara terlama saat membuka handphone. Di Indonesia, masyarakat bisa menghabiskan lebih dari 4 jam sehari untuk membuka aplikasi di handphone mereka. Ada 17 persen pengguna handphone sepanjang hari yang selalu membuka aplikasi, entah itu email, game, atau aplikasi streaming. Handphone semakin dibutuhkan dalam kehidupan sehari-hari, baik dalam kegiatan sosialisasi, pendidikan, bisnis, dan sebagainya. Tidak dapat dipungkiri bahwa media sosial mempunyai pengaruh yang besar dalam kehidupan seseorang. Seseorang yang awalnya kecil bisa menjadi besar dengan media sosial, atau sebaliknya. Bagi 
masyarakat khususnya kalangan siswa, handphone sudah menjadi candu yang membuat penggunanya tiada hari tanpa membuka handphone. Padahal dalam masa perkembangannya, di sekolah siswa berusaha mencari identitas dengan bergaul bersama teman-temannya, tetapi seiringan hal itu ada ketergantungan yang menyebabkan kesenjangan antar siswa dilingkungan sekolah yaitu kurangnya komunikasi langsung antar siswa diakibatkan dengan penggunaan hanphone yang sudah menjadi candu dikalangan para siswa.

Siswa zaman sekarang kemana-mana membawa handphone, makan sambil main handphone, ke kamar mandi membawa handphone, dan saat berjalanpun main handphone. Bangun tidur yang pertama kali dicari adalah handphone. Disini sudah terlihat betapa pentingnya handphone bagi remaja, hingga tidak bisa meninggalkan handphone sedetikpun.

Handphone memang memiliki banyak manfaat, tinggal bagaimana seseorang menggunakan handphone tersebut. Kemajuan teknologi yang serba canggih ini pasti menimbulkan dampak negatif dan positif, terutama bagi siswa saat ini. Siswa saat ini balum bisa memilih mana yang baik dan mana yang buruk, tetapi masih memburu kesenangannya saja. Tidak bisa dipungkiri rata-rata semua memiliki handphone, baik kalangan diperkotaan sampai keperdesaan. Pengaruh handphone terhadap siswa sangat cepat, bahkan ada siswa yang tidak mau sekolah hanya karena tidak di belikan handphone. Disini sudah terlihat bagaimana handphone itu sudah mempengaruhi siswa zaman sekarang.

Handphone disini sudah merubah pola pikir siswa zaman sekarang, banyak siswa yang melawan orang tua hanya karena handphone. Seperti yang di paparkan di atas remaja tidak mau sekolah hanya karena tidak dibelikan handphone, tidak mau makan karena tidak di belikan handphone, tidak mau membantu orang tua karena tidak di belikan handphone, seakan-akan handphone itu sudah menyatu dengan jiwa siswa zaman sekarang. Handphone memang penting, tapi seorang siswa yang menggunakan handphone harus diawasi orang tua, karena jika tidak diawasi akan berbahaya.

Dampak positif menggunakan handphone adalah mempermudah berkomunikasi dengan keluarga yang berada di luar kita bahkan luar negeri, bisa mengakses barbagai informasi sehingga kita dapat menambah wawasan dan tidak ketinggalan informasi penting, menjalin silaturahmi dengan sanak keluarga yang berada di luar kota bahkan luar negeri, dapat belajar menggunakan handphone karena kecanggihannya kita dapat belajar dengan handphone, cukup kita mencari di google kita dapat belajar dengan sesuka hati. Dampak negatif menggunakan handphone adalah dengan canggihnya alat komunikasi seperti handphone membuat seseorang malas untuk berkomunikasi langsung. Handphone juga mempengaruhi pola pikir dan tinggah laku siswa . Contohnya siswa yang sudah kecanduan permainan (games). Kemana-mana pasti membawa handphone dan tidur larut malam, disini membuat siswa tidak konsen terhadap pelajaran yang diberikan oleh gurunya. Handphone bisa dijadikan senjata penipuan bahkan kejahatan. Korban dari kejahatan ini adalah siswa, karena siswa saat ini masih labil dan mudah percaya kepada semua orang.

Adanya perubahan gaya hidup yang dialami oleh siswa yang mana sering mengalami waktu yang terbuang dan makin banyaknya konten-konten negatif yang bermunculan di media sosial. Seiring berkembangnya jaman, pemakaian hanphone semakin dituntut, akibatnya sekarang makin banyak jenis media sosial yang digunakan oleh siswa, contohnya yaitu Facebook, Line, Youtube, WA, Instagram dan apliklikasi game lainnya. Data dari survey yang dilakukan di salah satu Universitas di Indonesia menyatakan bahwa penggunaan media sosial dapat dengan tujuan hiburan, informasi, edukasi, dan pekerjaan, dimana hiburan mendominasi pemakaian media sosial. Pemakaian handphone tentunya memiliki sisi positif dan negatif dengan berbagai macam penggunaannya. Penelitian yang dilakukan dengan membandingkan efek yang diberikan oleh handphone terhadap perilaku siswa. 


\section{METODE PENELITIAN}

Dalam penelitian ini, penelitian akan menggunakan jenis penelitian kualitatif. Yaitu penelitian yang memberikan penejelasan tentang fakta berdasarkan obyek/sasaran fenomenologis yang berusaha mengungkap makna dibalik fakta. Menggunakan metode penelitian kualitatif karena data yang dikumpulkan bukan berupa angka, melainkan data tersebut berasal dari wawancara, catatan lapangan, dokumen pribadi, dan dokumen resmi lainnya. Penelitian ini termasuk penelitian kualitatif, bersifat deskriptif dan cenderung menggunakan analisis dengan pola nalar induktif. Penelitian ini menggunakan penelitian kualitatif karena peneliti ingin memperoleh penjelasan mengenai disparitas handphone terhadap perilaku siswa di lingkungan sekolah.

\section{HASIL DAN PEMBAHASAN}

\section{1) Handphone mengganggu proses belajar mengajar}

Pada saat siswa berangkat ke sekolah banyak siswa yang tetap membawa handphone ke sekolah karena tidak ada larangan membawa handphone ke dan disisi lain juga mengisi kekosongannya pada saat jam istirahat, pada saat istirahat banyak siswa yang ke kantin untuk makan dan ada juga yang pergi ke kantin untuk mengunakan handphone nya dan ada juga yang tinggal di kelas main handphone, melihat fenomena seperti ini dimana pengaruh handphone terhadap siswa sangat besar karena dapat mengurangi minat belajar dan minat membaca peserta didik. Tujuan utama siswa ke sekolah yaitu untuk belajar dan untuk menuntut ilmu dan menempuh yang namanya pendidikan. Sebagaimana pendapat Nanang Martono (2012: 194), posisi pendidikan sebagai subjek dalam proses perubahan sosial berkaitan erat dengan fungsi pendidikan sebagai agen of change. Pendidikan merupakan sebuah proses transfer ilmu pengetahuan, dapat pula dimaknai sebagai proses penanaman nilai kepada individu.

\section{2) Belenggu handphone sebagai krisis prestasi belajar siswa}

Keberhasilan handphone menggerogoti pikiran orang, tak disadari imperialisme budaya pun merajalela. Kini handphone adalah sakunya anak didik. Handphone juga mempengaruhi etika tingkah laku penggunanya. Dan handphone dapat menjauhkan individu dari lingkungan masyarakat dan dikalangan pelajar handphone dapat mempengaruhi bahkan menurunkan prestasi dan minat belajar siswa. Permasalahan timbul sebenarnya bukan dari perangkat tersebut di zaman sekarang ini, akan tetapi kalangan pengguna perangkat tersebut yang menyalahgunakannya. Hal ini pendapat Prof. Dr. Soerjono Soekanto (2013: 225), Apabila semua kewajiban selalu sesuai dengan keinginan si individu, dan sesuai pula dengan kemanpuan-kemanpuannya dan seterusnya, persoalan tak akan terlalu sulit untuk dilaksanaka. Akan tetapi, kenyataan tidaklah demikian.

\section{3) Penyalahgunaan Handphone Oleh Siswa}

Banyak siswa yang sudah kecanduan dengan handphone dan susah terpisah dengan handphone nya, kapan pun dan dimanapun berada pasti membawa handphone termasuk ke sekolah dan salahnya menggunakan handphone bukan untuk belajar tapi untuk main game. Sekolah sudah memberikan larangan untuk siswa supaya tidak membawa handphone ke sekolah tapi siswa tetap ada yang membawa handphone karena katanya untuk mencari materi pelajaran dan hubungi orang tua ketika pulang sekolah tapi nyatanya siswa salah gunakan handpone nya. Hal ini sesuai dengan Teori Tindakan (Talcot Parsons) atau action theory adalah perspektif sosiologis yang menitikberatkan pada individu sebagai sebuah subjek. Teori tindakan memandang aksi atau tindakan social sebagai sesuatu yang secara sengaja dibentuk oleh individu dalam konteks yang diberi makna oleh mereka. 


\section{4) Multifungsi Handphone di SMA Muhammadiyah Sungguminasa}

Perlu dilakukan sosialiasi penggunaan handphone yang benar dilingkungan sekolah. Sosisalisasi yang dilakukan bertujuan supaya siswa bisa memanfaatkan handphone kearah yang posistif, seperti mencari materi pembelajaran yang sedang diajarkan oleh gurunya. Sosialisasi juga bertujuan supaya siswa tidak terlalu berlebihan dalam menggunakan handphone nya ketika berada dalam lingkungan sekolah karena dapat mempengaruhi karakter dan kepribadian siswa. Adanya peran orang tua untuk selalu mengawasi anaknya. Orang tua harus bekerja sama dengan guru untuk mengarahkan anaknya menjadi siswa yang berprestasi. Pengawasan orang tua terhadap anaknya sangatlah perlu karena tempat pertama memperoleh pendidikan yaitu dikeluarga jadi orang tua harus mengawasi dan selalu membimbing serta menasehati anaknya terhadap masalah penggunaan handphone ketika berada di lingkungan sekolah. Sebagaimana pendapat Bambang Pranowo (2013: 23), perspektif fungsionalis menekankan keteraturan (order) dan stabilitas dalam masyarakat bahwa bagian-bagian dari sebuah system social bekerja sama untuk menopang kesatuan system tersebut, misalnya pada sekolah yaitu kerja sama antara kepala sekolah, guru dan orang tua dalam mengawasi anak didiknya.

\section{5) Disparitas Pengguna Handphone Siswa terhadap Prestasi Belajar di SMA Muhammadiyah Sungguminasa}

Di SMA Muhammadiyah Sungguminasa hampir semua siswa menggunakan handphone, data dari hasil observasi, sekitar $85 \%$ dari pelajar SMA Muhammadiyah Sungguminasa telah menggunakan dan memakai handphone ber-smartphone. Tingginya angka pelajar menggunakan handphone ini sangat miris, karena siswa menggunakannya tidak kenal waktu. Di sekolah sudah ada beberapa pelajar yang bisa menggunakan handphone pada saat jam pelajaran berlangsung, misalnya pelajaran bhs inggris dan matematika, tetapi ada beberapa siswa yang tetap menggunakan handphone nya diluar dari pelajaran tersebut. Hal ini dimungkinkan karena rendahnya pula guru yang mengawasi dan tidak ada teguran sama sekali. Rendahnya mutu hasil belajar, dari beberapa ahli (Djemari Mardapi 1999: 11) mengatakan bahwa, dalam lima tahun terakhir hasil Ujian Nasional (UN) murni Sekolah Menengah Pertama (SMP) dan Sekolah Menengah Umum (SMU) menunjukkan angka naik turun dengan rata-rata Nilai Ujian Nasional (UN) murni bergerak antara 4,00-6,00. Kesimpulan yang saya dapatkan dari internet berdasarkan ahli: Sementara (Achmad Lutfi, 2002: 35) mengatakan, rendahnya mutu hasil belajar disebabkan oleh keuletan siswa pada umumnya rendah.

\section{6) Disparitas Handphone terhadap Prestasi Belajar Siswa}

Jika sudah sekali memakai handphone pasti akan kecanduan ingin memakai itu terus, seperti sama halnya dengan narkoba bila sudah memakai sekali pasti ingin terus menerus memakai itu. Handphone rasanya sangat merasuki pikiran semua orang di dunia ini, jika tidak punya handphone rasanya ada yang kurang. Handphone juga dapat menimbulkan dampak negatif terhadap prestasi belajar para siswa. Hal ini dikarenakan penyalahgunaan handphone oleh para siswa sehingga handphone juga dapat membuat prestasi para pelajar menurun, bukan yang seharusnya siswa rajin dan pintar saat ada handphone malah menjadi malas dan bodoh.

\section{7) Ketergantungan Handphone Pembentuk Kesenjangan Siswa}

Tantangan dunia pendidikan adalah etika, etika moral seorang siswa, hal ini tercermin dari ditemukannya beberapa handphone siswa yang berisikan video porno, hal ini menunjukkan kurangnya kesadaran siswa akan moral. Kini dunia handphone adalah dunia untuk berkomunikasi, berbagi, mencipta dan menghibur dengan suara, tulisan, gambar, musik dan video. Disamping harga yang ditawarkan cukup terjangkau, berbagai fitur handphone juga diberikan sebagai penunjang majunya teknologi.Namun terkadang juga handphone dapat mengganggu atau memiliki beberapa hal negatif diantaranya tempat untuk menyimpan gambar-gambar porno,atau menggunakan 
handphone saat tengah diadakan proses belajar yang dapat mengganggu siswa atau perhatian dan minat mereka dalam belajar menjadi berkurang di karenakan mereka lebih sibuk untuk saling berkiriman pesan. Hal ini sesuai dengan Teori Interaksi Simbolik, pendekatan ini focus pada proses interaksi dalam institusi pendidikan seperti sekolah dan outcome dari interaksi tersebut. Sebagai contoh, interaksi antara guru dan murid di sekolah.

Teori Interaksi Simbolik melihat bagaimana karakteristik sosial membentuk interaksi social seperti interaksi antar gender, kelas, ras dan sebagainya, dan bagaimana interaksi tersebut menciptakan ekspektasi antara guru dan murid.

\section{KESIMPULAN}

Berdasarkan pemaparan hasil penelitian dan analisisnya mengenai Belenggu Produk Modernisasi Terhadap Disparitas Siswa (Studi Kasus Penggunaan Handphone di Lingkungan SMA Muhammadiyah Sungguminasa). Peneliti dapat mengambil kesimpulan bahwa:

1. Berdasarkan hasil obervasi awal di SMA Muhammadiyah Sungguminasa peneliti dapat mengambil kesimpulan bahwa handphone sangat mengganggu proses belajar mengajar dan dapat menyebabkan krisis prestasi belajar karena banyak siswa yang menyalahgunakan handphone nya kearah yang negatif. Handphone sebenarnya bisa memberikan dampak positif bagi siswa jika difungsikan sebagaimana mestinya dan itu perlu pengawasan ketat dari guru untuk mengontrol anak didiknya supaya dapat meningkatkan prestasi belajar siswa.

2. Handphone dapat menyebabkan ketergantungan bagi siswa sehingga timbul ketergantunggan yang membentuk kesenjangan antar siswa baik dalam aspek pergaulan maupun dari aspek komunikasi dan keterbukaan sehingga dapat mempengaruhi prestasi belajar siswa.

\section{DAFTAR PUSTAKA}

Upe, Ambo. 2010. Tradisi Aliran dalam Sosiologi. Jakarta, PT. Raja Grafindo Persada Poloma, Margaret M. 2010. Sosiologi Kontemporer. Jakarta, PT. RajaGrafindo Persada Pranomo, Bambang M. 2013. Sosiologi Sebuah Pengantar. Tanggerang, Laboratorium Sosiologi Agama

Soekanto, Soerjono. 2007. Sosiologi Suatu Pengantar. Jakarta: Rajawali Pers.

globalisasi-dan-modernisasi

Lauer, Robert H. 2001. Prespektif Tentang Perubahan Sosial. Jakarta: PT Asdi Mahasatya.

Shadily, Hasan. 1963. Sosiologi Untuk Masyarakat Indonesia. Jakarta, PT. Pembangunan

Susanto, Phil Astrid S. 1999. Pengantar Sosiologi dan Perubahan Sosial. Jakarta. Putra A. Bardin

Ciremai, Anak. (2010). Makalah Modernisasi dan Globalisasi.

Boudrillard, Jean P. 2004, Masyarakat Konsumsi. Yogyakarta: Kreasi Wacana.

Effendy, Onong Uchjana, 2005. Komunikasi dan Modernisasi. Bandung: Mandar Maju.

Kleden, Ninuk dan Probonegoro, 2004. Ekspresi Karya (Seni) dan Politik Multikultural: Sebuah Pengantar. Jakarta : Lembaga Ilmu Pengetahuan Indonesia.

Nazaruddin, Muzayin dan Masduki, 2008. Media, Jurnalisme dan Budaya Populer. Yogyakarta: UII Press.

Tikson, T. Deddy, 2005. Keterbelakangan dan Ketergantungan : Teori Pembangunan di Indonesia, Malaysia, dan Thailand. Makassar : Ininnawa.

Sardiman, A.M. (2004). Interaksi \& Motivasi Belajar Mengajar. Jakarta: PT Raja Grafindo

Persada.

Ametembun, N. A. 1981. Supervisi Pendidikan Penuntun Bagi Para Kepala Sekolah dan

Guru-Guru, Suri, Bandung: Suri.

Mulyasa. 2002. Kurikulum Berbasis Kompetensi. Bandung: Remaja Rosdakarya.

Soedijarto. 1991. Mencari Strategi Pengembangan Pendidikan Nasional Menjelang Abad XXI. Jakarta: PT. Grasindo. 
Tilaar, H. A. R. 1990. Pendidikan Dalam Pembangunan Nasional Menyongsong Abad XXI. Jakarta: Balai Pustaka.

Zamroni. 2001. Paradigma Pendidikan Masa Depan. Yogyakarta: Bigraf Publishing.

http://www.afand.cybermq.com/post/detail/2761/dampak-positif-dan-dampak-negatif http://www.wikipedia.com (diakses pada 10 Mei 2019)

http://id.shvoong.com, (diakses pada 10 Mei 2019) 